\title{
ON THE VALUE OF A POSTPONED LIFE INTEREST.
}

To the Editor of the Journal of the Institute of Actuaries.

Sir,-In January 1892, Dr. Sprague contributed to the Journal a "Case and Opinion regarding the Value of the Life Interest of a Lady in a Reversion expectant on her own death" (J.I.A., xxix, 540). The point of contention was as to what part of the sum realized the lady's executors should receive in respect of the income to which she was entitled from the date of the testator's death; and 
Dr. Sprague thought that the course laid down in the Opinion seemed the best that could be adopted, except that allowance should be made for the time elapsed between the death of the lady and the actual realization of the reversion, by dividing the sum ascertained as income proportionately between the two estates.

The question as to the proper sum that should be paid in respect of income postponed through the non-conversion of a reversion is, I believe, one that has not been settled entirely to the satisfaction of lawyers, and the following case, in which the point required to be dealt with in a different way from that mentioned above, may be of interest to readers of the Journal. In the following case, the person who was entitled, under a will, to a life interest in the proceeds of a reversion, to be converted at the testatrix's death, was not the life upon which the reversion was expectant; and the reversion did not, therefore, fall in upon the death of the lady, whose executors claimed a payment in respect of her postponed income.

\section{CaSE.}

Miss A, by her will, dated 4 April 1889, bequeathed the residue of ber property upon trust for sale and conversion and investment of the proceeds; and to pay the income of such sale and conversion, and the actual income of her property until converted to her mother, Mrs. A, during her life.

Miss A died on 28 June 1889, leaving her mother surviving.

Mrs. A died on 20 January 1891.

Miss A's property included a vested reversionary interest in a sum of $£ 3,000$ Consols expectant on the death of a Mrs. D. This reversionary interest was not sold, but fell in by the death of this Mrs. D on 8 May 1891. Counsel was asked to advise what, if anything, the estate of Mrs. A is entitled to in respect of her daughter's reversionary interest, and how, and on what principles, the amount (if any) due to Mrs. A's estate should be ascertained, regard being had to the fact that she died before the reversion fell into possession on the death of Mrs. D.

The above case was first submitted to Counsel, who gave the following opinion:-

"Upon the principle laid down in the case of Howe $v$. Dartmouth “ (7 Vesey 137) Mrs. A was entitled to have her daughter's reversionary " interest converted, and the income of its conversion paid to her "during her life. As this was not done, Mrs. A's estate, now that "the reversionary interest has fallen in, is entitled to have made "good to it the amount which would have been paid to Mrs. A if " the reversionary interest had been sold. The mode of ascertaining " this amount is prescribed by such cases as the Earl of Chesterfield's "Trusts (24 Ch. Div. 643) and re Hobson (34 W. R. 70). As "Mrs. A died before the reversion fell into possession, her estate is " entitled, when the amount of the income shall have been ascertained 
" in the manner mentioned in those two cases, to such proportion of " that amount as the time she lived after Miss A's death bears to " the time which elapsed between Miss A's death and the time when " the reversion fell into possession."

An Action was subsequently instituted, the decision of the Court being as follows:

The Court agreed with the above opinion, in so far as it decided that a sum ought to be paid to Mrs. A's executors, and that the principle on which this sum ought to be ascertained was that laid down in the cases to which Counsel referred; but special reference was made to Mr. Justice Kay's judgment in re Hobson "at top of 72nd page of 34 W. R."; and the Order went on to say that "the " sum to be paid ought to be ascertained by calculating what sum, "put out at 4 per-cent per annum on the day of the death of "Miss A, namely, 28 June 1889, and accumulated at compound " interest at the same rate, with yearly rests, and deducting income " tax, would, with the accumulations of interest, amount on the day " of the death of Mrs. A to the Value of the Reversionary Interest "on such day, and that the difference between these two sums "represents the income which is payable to the executors of "Mrs. A."

An important difference between Counsel's Opinion and the Court Order will be at once remarked. While Mrs. A's estate would, aceording to the former, benefit by the reversion falling in soon after her death, the latter does not allow this, but bases the calculation upon the value of the reversion at Mrs. A's death; the latter course being more in accordance with Mr. Justice Kay's judgment in re Hobson, to which special attention was directed in the Court Order. In this case, $r e$ Hobson, a testator by will bequeathed personal estate upon trust after payment of debts, \&c., to lay out and pay income to plaintiff for life with remainders. Part of the residuary estate consisted of a contingent reversionary interest in certain funds. Testator died in 1832; and the reversion first became saleable in 1846, but it had never been sold. Since the latter date the reversion had increased enormously in value. Upon an application in effect to have the value of the reversion apportioned as between life tenant and remainder-men, $\mathrm{Mr}$. Justice Kay decided that, as both parties had been interested in keeping the reversion unsold, it must be assumed to be sold at an agreed price and apportioned in the manner above stated. He decided also that there was no difference between the realization of a reversion by sale and its falling iu; and that contingent and vested reversions must be treated in the same way, for the latter might be dependent upon several lives and have practically no value at first.

It is, however, worth mentioning that, in the case of an absolute reversion dependent on one life, the sum apportioned to the life tenant in the above manner will be less than the accumulations at compound interest of the sum the reversion would have realized at testator's death, had such sum been then invested at 4 per-cent. The value of an ordinary absolute reversion increases annually at a considerably less rate than 4 per-cent; in the present case, for example, the increase 
in value was only about $1 \frac{3}{4}$ per-cent. Taking into account, however, the various contingencies that may arise, if the reversion be not converted at the first, the course recommended by the Court seems the most equitable that could be adopted.

$$
\begin{aligned}
& \text { I am, Sir, } \\
& \text { Your obedient Servant, } \\
& \text { J. R. HAR'T, F I.A. }
\end{aligned}
$$

26 St. Andrew Square,

Edinburgh,

8 March 1895.

\section{MR. RYAN'S PAPER ON VALUATIONS FOR SOLVENCY.}

To the Editor of the Journal of the Institute of Actuaries.

Srn,-In the hope that they may be of interest, I send herewith tables for endowment assurances payable at age 60, corresponding to those for the whole term of life given in Mr. Ryan's paper recently read before the Institute.

In Mr. Ryan's tables, as well as in my own, I am somewhat surprised to find that the percentage of the reserve values to the premiums paid in certain cases first of all diminishes with the increased duration of the policy and then increases again. The point seems to me worthy of further investigation, and I find that a very simple formula will give the value of $n$ when the percentages cease to diminish or commence to increase.

$$
\text { We have } \quad \frac{{ }_{n} \mathrm{~V}_{x}}{n \mathrm{P}_{x}}>=<\frac{{ }_{n+1} \mathrm{~V}_{x}}{(n+1) \mathrm{P}_{x}} . . . .
$$

according as $(n+1)_{n} \mathrm{~V}_{x}>=<n_{n+1} \mathrm{~V}_{x}$

according as $\frac{{ }_{n} \mathrm{~V}_{x}}{{ }_{n+1} \mathrm{~V}_{x}-{ }_{n} \mathrm{~V}_{x}}>=<n$. . . . . . . . . .

It should be noted that the tables in Mr. Ryan's paper are concerned with the ratios of the successive terms in the two following series:

$$
\begin{aligned}
& n \mathrm{P}_{x},(n+1) \mathrm{P}_{x},(n+2) \mathrm{P}_{x}, \& c . \\
& { }_{n} \mathrm{~V}_{x},{ }_{n+1} \mathrm{~V}_{x},{ }_{n+2} \mathrm{~V}_{x}, \& c .
\end{aligned}
$$

The first of these two series is in arithmetical progression, and its differences are a constant quantity $\left(=P_{x}\right)$. 